\title{
Molecular Modelling and in Vitro Hypoglycemic Examination of Polysubstituted Quinoline Derivatives
}

\author{
Gangadhara Angajala, Valmiki Aruna, Radhakrishnan Subashini, Geetha Das, Ramanathan \\ Rajajeyaganthan
}

\begin{abstract}
In the present work in-silico molecular simulations were carried out to find out the binding affinities of synthesized polysubstituted quinolines towards PPAR protein $(2 X K W)$. The results obtained from docking analysis showed that the synthesized polysubstituted quinoline derivatives 1 a-g are having stronger binding interactions which was on par to that of standards rosiglitazone and pioglitazone. In addition to this in-vitro hypoglycemic studies were studied through a-amylase and $\alpha$-glucosidase enzyme inhibition assays. The results showed that compounds $1 c$ and 1d possess good hypoglycemic efficacy with percentage inhibition of $87.94 \pm 0.25,85.90 \pm 0.56$ towards $\alpha$-glucosidase and $84.55 \pm 1.02,82.14 \pm 0.26$ percent inhibition towards a-amylase which was greater than standard rosiglitazone and comparable to standard pioglitazone
\end{abstract}

Keywords: Quinolines, PPAR, Hypoglycemic

\section{INTRODUCTION}

Quinolines and their analogues are considered as an important class of bioactive heterocyclic compounds because of its versatile applications in the field of pharmaceuticals and in various biological systems [1-5]. Quinoline scaffolds because of their varied biological activities like antimicrobial, antioxidant, antimalarial (chloroquine and mefloquine), anticancer, antiinflammatory, cytotoxic agents, tyrosine kinase PDGF-RTK inhibitor and topoisomerase I inhibitors have great significance among heterocycles [4-8]. In addition to medicinal applications, quinoline derivatives are found to undergo hierarchical self-assembly into a variety of nano-structures and meso-structures with enhanced electronic and photonic functions [9-12]. In recent years quinoline scaffold was widely used in the design and

Revised Manuscript Received on December 22, 2019.

* Correspondence Author

Gangadhara Angajala*, Chemistry, Kalasalingam Academy of Research and Education, Krishnankoil, Virudhunagar, India.

Email: gangadharaangajala@gmail.com

Valmiki Aruna, Chemistgry, Kalasalingam Academy of Research and Education, Krishnankoil, Virudhunagar, India.

Email: aruna.prahan@gmail.com

Radhakrishnan Subashini, Chemistry, Arignar Anna Government Arts College for women, Walajapet-632513, India.

Email: dr.subashini.r@gmail.com

Geetha Das, Chemistry, Kalasalingam Academy of Research and Education, Krishnankoil, Virudhunagar, India.

Email: geethachem2015@gmail.com

Ramanathan Rajajeyaganthan, Chemistry, Kalasalingam Academy of Research and Education, Krishnankoil, Virudhunagar, India.

Email: rajajeyaganthan.r@klu.ac.in synthesis of new hypoglycemic agents [13]. Diabetes mellitus (DM) is considered as the world's largest growing metabolic non-communicable disease. Diabetes are at an increased risk of developing chronic complications related to cardiovascular, ophthalmic, neurological, renal and peripheral vascular diseases. Inspite of the releasing various hypoglycemic agents, diabetes and its associated secondary complications continue to be a major problem in the world population. Literature search reveals only little amount of work has been carried out regarding molecular docking analysis of polysubstituted quinoline derivatives towards PPAR $\gamma$ (Peroxisome Proliferator Activated ReceptorGamma) protein. The purpose of the present investigation was to find out the binding affinity studies of various polysubstituted quinolines with PPAR $\gamma$ protein and its in vitro hypoglycemic studies using $\alpha$-amylase and glucosidase enzyme inhibition assays

\section{MATERIALS AND METHODS}

\section{A. Synthesis of Polysubstituted Quinolines}

The synthesis of polysubstituted quinolines by the reaction of 2-aminoaryl ketone with enolizable ketone in the presence of nickel nano catalyst was already reported in our previous work [14] (Scheme.1) (Fig.1).

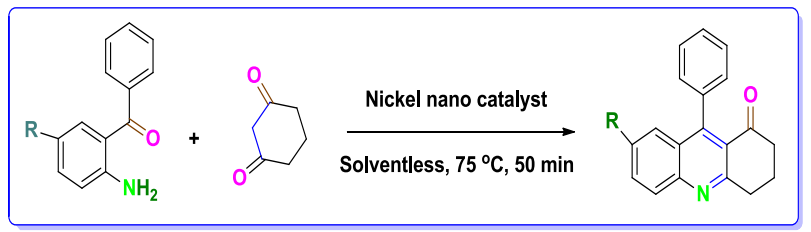

Scheme. 1. Synthesis of polysubstituted quinolines

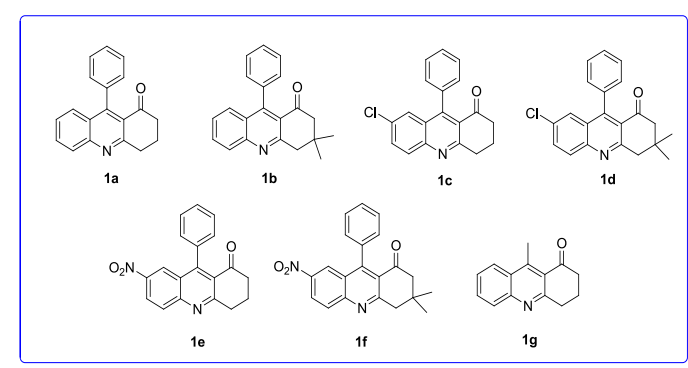

Fig.1.Polysubstituted quinoline analogues

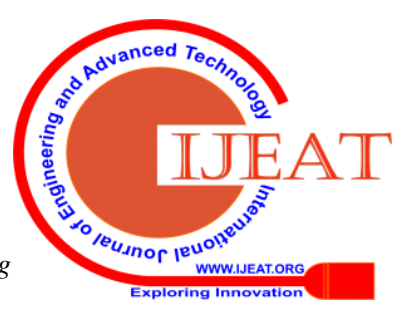




\section{B. Molecular Modelling Studies}

The binding affinity of polysubstituted quinoline analogues (1a-g) with PPAR $\gamma$ were analyzed by using Autodock.v.1.5.6. The protein PPAR $\gamma$ was taken from protein data bank (ID: $2 \mathrm{XKW}$ ). Evaluation of rapid energy was carried out effectively by evaluating atomic affinity potential for individual ligand separately and the energy of interaction of each atom in the ligand was encountered. Finally grid maps were calculated for each ligand separately and docking analysis were carried out by using Lamarckian Genetic Algorithm. In order to predict docking energy for each derivative, Autodock was initiated various times to get several confirmations of docking ligand with the receptor grid. By using Autodock 4.2 scoring functions 5 best confirmations were generated for all ligands. Evaluation of the docking results were done by simultaneously sorting the different complexes with respect to the predicted binding energies.

\section{In Vitro Hypoglycemic Studies}

In vitro hypoglycemic efficacy of the synthesized polysubstituted quinoline derivatives (1a-g) were carried out by using $\alpha$-amylase and $\alpha$-glucosidase assays. Patients suffering from type 2 diabetes when treated with drugs that prevent carbohydrate hydrolyzing enzymes has proved to display significant decrease in postprandial blood glucose levels along with increased metabolism of glucose without stimulating secretion of insulin. By using enzyme-starch system the effect of compounds $3 \mathrm{a}$-h on $\alpha$-amylase activity was studied as per procedure given by Malik and his coworkers [15]. $\alpha$-glucosidase inhibitors which act as competitive inhibitors of intestinal $\alpha$-glucosidase can delay the digestion and subsequent absorption of elevated blood glucose levels. A crude enzyme solution of rat intestinal $\alpha$-glucosidase was employed to assay the $\alpha$-glucosidase inhibitory activity as per the procedure given by Krishnaveni and her coworkers [16].

\section{- $\alpha$-glucosidase inhibition}

A solution containing $1 \mathrm{~mL}$ of starch substrate $(2 \% \mathrm{w} / \mathrm{v}$ sucrose or maltose), 0.2 M Tris buffer having $\mathrm{pH} 8.0$ and different concentration of synthesized quinoline products 1a-g were incubated at temperature of $37^{\circ} \mathrm{C}$ for a period of $5 \mathrm{~min}$. The reaction was started by the addition of $1 \mathrm{~mL}$ $\alpha$-glucosidase enzyme $(1 \mathrm{U} / \mathrm{mL})$ to the above reaction mixture and further incubating at $35{ }^{\circ} \mathrm{C}$ for $40 \mathrm{~min}$. After incubation by adding $2 \mathrm{~mL}$ of $6 \mathrm{~N} \mathrm{HCl}$ the reaction was finally terminated. The color intensity developed in the reaction mixture was measured at $540 \mathrm{~nm}$. Then the reaction was terminated by the addition of $2 \mathrm{~mL} 6 \mathrm{~N} \mathrm{HCl}$. The experiment was carried out in triplicate and the percentage inhibition of enzyme activity was calculated as follows Percentage inhibition $(\mathrm{I} \%)=($ Ac-As $) / A c$ X 100 Where Ac $=$ Absorption of control; As = Absorption of sample

\section{- $\alpha$-amylase inhibition}

$\alpha$-amylase assay was carried out as per the procedure given by Malik and his coworkers by using starch-iodine method.
To the reaction mixture various concentration of the synthesized polysubstituted quinoline derivatives $1 \mathrm{a}-\mathrm{g}(50$, $100,250 \mu \mathrm{g} / \mathrm{ml}$ ) was added which initially contains $10 \mathrm{~mL}$ of $\alpha$-amylase solution $(0.025 \mathrm{mg} / \mathrm{mL}), 400 \mathrm{~mL}$ of phosphate buffer solution ( $\mathrm{pH}$ 7.0). After incubation for a period of 10 min at $37{ }^{\circ} \mathrm{C}$, to the reaction mixture $100 \mathrm{~mL}$ of starch solution (1\%) was added and further subjected to incubation for $60 \mathrm{~min}$ at $37{ }^{\circ} \mathrm{C}$. Later $5 \mathrm{~mL}$ distilled water followed by $0.1 \mathrm{~mL}$ of $1 \%$ iodine solution was added and the absorbance was recorded at $565 \mathrm{~nm}$. Blank analysis was performed maintaining similar reaction conditions to test solution, reactants and for enzyme $\alpha$-amylase. The experiment was carried out in triplicate and the percentage inhibition of enzyme activity was calculated as follows

Percentage inhibition $(\mathrm{I} \%)=(\mathrm{As}-\mathrm{Ac}) /(\mathrm{Ab}-\mathrm{Ac}) \times 100$

where, As = absorbance of the sample, $\mathrm{Ab}=$ absorbance of blank (without $\alpha$-amylase) and Ac $=$ absorbance of control (without starch).

\section{RESULTS AND DISCUSSION}

\section{A. Molecular docking analysis}

The protein-ligand based interactions play a crucial role in structural based drug design. The most stable docking conformation of the synthesized polysubstituted quinoline derivatives in complex with PPAR $\gamma$ protein as depicted in Fig.2 evidently specify that the quinoline analogues are having greater binding interactions with the receptor which was compared to that of standards rosiglitazone, and pioglitazone. The results obtained from effective binding interactions of synthesized compounds $1 \mathrm{a}-\mathrm{g}$ with various amino acids of the protein showed that compound $1 \mathrm{c}$ and $1 \mathrm{~d}$ possess excellent binding interaction towards PPAR $\gamma$ with binding energy of $-9.0 \mathrm{k} . \mathrm{cal} / \mathrm{mol}$ and $-8.9 \mathrm{k} . \mathrm{cal} / \mathrm{mol}$ which was on par to that of standards rosiglitazone $(-9.2 \mathrm{k} . \mathrm{cal} / \mathrm{mol})$ and pioglitazone (-9.8) whereas compound 1a possess moderate binding interaction with docking score of $(-8.7$ $\mathrm{k} . \mathrm{cal} / \mathrm{mol}$ ) respectively (Table-I). The interaction of compound $1 \mathrm{c}$ and $1 \mathrm{~d}$ with various amino acids of the PPAR $\gamma$ protein was depicted in Fig.3.

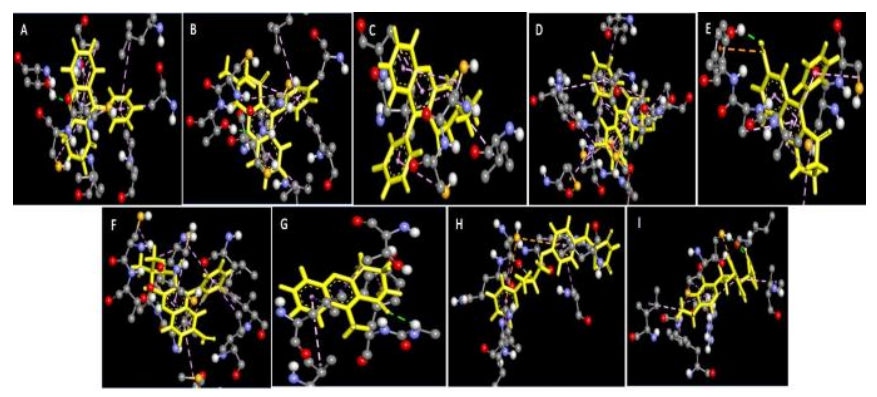

Fig.2. Binding interactions of 1a-g with PPAR $\gamma$ protein [A] Interaction of compound $1 \mathrm{a}[\mathrm{B}]$ Interaction of compound $1 \mathrm{~b}$ [C] Interaction of compound 1c [D] Interaction of compound 1d [E] Interaction of compound 1e [F] Interaction of compound $1 \mathrm{f}[\mathrm{G}]$ Interaction of compound $1 \mathrm{~g}$ $[\mathrm{H}]$ Interaction of standard rosiglitazone [I] Interaction of standard pioglitazone 


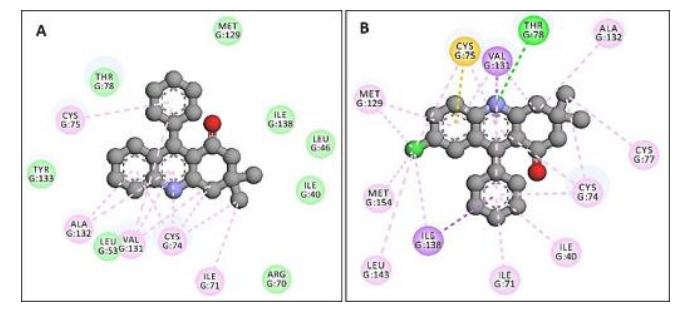

Fig.3. Binding interactions of 1c and 1d with various aminoacids of PPAR $\gamma[\mathrm{A}]$ Compound 1c interactions [B] Compound 1d interactions

Table-I: In silico molecular docking analysis for hypoglycemic efficacy of the synthesized polysubstituted quinoline derivatives, 1a-g and standards

\begin{tabular}{ccc}
\hline S.No & Ligand & Autodock Score \\
\hline 1 & $1 \mathrm{a}$ & -8.7 \\
2 & $1 \mathrm{~b}$ & -8.5 \\
3 & $1 \mathrm{c}$ & -9.0 \\
5 & $1 \mathrm{~d}$ & -8.9 \\
6 & $1 \mathrm{e}$ & -8.1 \\
7 & $1 \mathrm{f}$ & -7.8 \\
8 & $1 \mathrm{~g}$ & -8.0 \\
9 & Std $^{\mathrm{a}}$ & -9.2 \\
10 & Std $^{\mathrm{b}}$ & -9.8 \\
\hline
\end{tabular}

${ }^{\mathrm{a}}$ Rosiglitazone, ${ }^{\mathrm{b}}$ Pioglitazone

\section{B. In Vitro Hypoglycemic Studies}

From in-vitro enzyme inhibition analysis towards hypoglycemic activity out of the synthesized quinoline derivatives 1a-g compounds $1 \mathrm{c}$ and $1 \mathrm{~d}$ showed $87.94 \pm 0.25$ and $85.90 \pm 0.56$ percent inhibition towards $\alpha$-glucosidase, $84.55 \pm 1.02$ and $82.14 \pm 0.26$ percent inhibition towards $\alpha$-amylase which was greater than standard rosiglitazone $(74.06 \pm 0.07,72.91 \pm 0.24)$ and comparable to pioglitazone $(89.28 \pm 0.82,85.36 \pm 0.47)$, Acarbose $(91.60 \pm 0.18,87.19$ $\pm 0.55)$ (see Table-II and Table-III, Fig.3 and Fig.4).

Table-II: $\alpha$-glucosidase inhibitory efficacy of polysubstituted quinoline derivatives (1a-g)

\begin{tabular}{|c|c|c|c|c|}
\hline S.No & Compound & \multicolumn{3}{|c|}{ Concentration $(\mu \mathrm{g} / \mathrm{ml})$} \\
\hline & & 50 & 100 & 250 \\
\hline 1 & $1 \mathrm{a}$ & $34.18 \pm 0.42$ & $53.29 \pm 0.14$ & $85.21 \pm 0.62$ \\
\hline 2 & $1 \mathrm{~b}$ & $32.16 \pm 0.45$ & $51.33 \pm 0.69$ & $81.58 \pm 0.42$ \\
\hline 3 & $1 \mathrm{c}$ & $35.67 \pm 0.30$ & $56.29 \pm 0.10$ & $87.94 \pm 0.25$ \\
\hline 4 & $1 d$ & $34.79 \pm 0.40$ & $54.75 \pm 0.12$ & $85.90 \pm 0.56$ \\
\hline 5 & $1 \mathrm{e}$ & $31.20 \pm 0.05$ & $50.22 \pm 0.72$ & $78.12 \pm 0.15$ \\
\hline 6 & 1f & $30.44 \pm 0.95$ & $49.14 \pm 0.68$ & $77.43 \pm 0.80$ \\
\hline 7 & $1 \mathrm{~g}$ & $28.40 \pm 0.20$ & $46.55 \pm 0.71$ & $73.28 \pm 0.10$ \\
\hline 8 & $\operatorname{Std} 1^{\mathrm{a}}$ & $29.64 \pm 0.19$ & $47.24 \pm 0.18$ & $74.06 \pm 0.07$ \\
\hline 9 & $\operatorname{Std} 2^{b}$ & $37.22 \pm 0.10$ & $56.78 \pm 1.22$ & $89.28 \pm 0.82$ \\
\hline 10 & $\mathrm{Std} 3^{\mathrm{c}}$ & $38.95 \pm 0.22$ & $58.10 \pm 0.55$ & $91.60 \pm 0.18$ \\
\hline
\end{tabular}

${ }^{\mathrm{a}}$ Pioglitazone; ${ }^{\mathrm{b}}$ Rosiglitazone; ${ }^{\mathrm{c}}$ Acarbose
Table-III: $\alpha$-amylase inhibitory efficacy of polysubstituted quinoline derivatives (1a-g)

\begin{tabular}{|c|c|c|c|c|}
\hline S.No & Compound & \multicolumn{3}{|c|}{ Concentration $(\mu \mathrm{g} / \mathrm{ml})$} \\
\hline & & 50 & 100 & 250 \\
\hline 1 & $1 \mathrm{a}$ & $32.19 \pm 0.62$ & $52.46 \pm 1.44$ & $80.11 \pm 0.26$ \\
\hline 2 & $1 b$ & $32.69 \pm 0.15$ & $48.72 \pm 0.73$ & $78.24 \pm 0.18$ \\
\hline 3 & $1 \mathrm{c}$ & $34.47 \pm 0.90$ & $53.18 \pm 0.85$ & $845.5 \pm 1.02$ \\
\hline 4 & $1 d$ & $34.08 \pm 0.23$ & $52.95 \pm 0.56$ & $82.14 \pm 0.26$ \\
\hline 5 & $1 \mathrm{e}$ & $32.97 \pm 0.25$ & $50.02 \pm 0.76$ & $79.85 \pm 0.17$ \\
\hline 6 & 1f & $31.76 \pm 0.81$ & $48.92 \pm 0.10$ & $73.15 \pm 0.29$ \\
\hline 7 & $1 \mathrm{~g}$ & $31.05 \pm 0.62$ & $46.97 \pm 0.24$ & $75.31 \pm 1.04$ \\
\hline 8 & $\operatorname{Std} 1^{\mathrm{a}}$ & $28.00 \pm 0.68$ & $46.78 \pm 0.22$ & $72.91 \pm 0.24$ \\
\hline 9 & $\operatorname{Std} 2^{\mathrm{b}}$ & $34.92 \pm 0.55$ & $54.25 \pm 1.35$ & $85.36 \pm 0.47$ \\
\hline 10 & $\operatorname{Std} 3^{c}$ & $36.15 \pm 0.28$ & $57.10 \pm 0.74$ & $87.19 \pm 0.55$ \\
\hline
\end{tabular}

${ }^{\mathrm{a}}$ Pioglitazone; ${ }^{\mathrm{b}}$ Rosiglitazone; ${ }^{\mathrm{c}}$ Acarbose

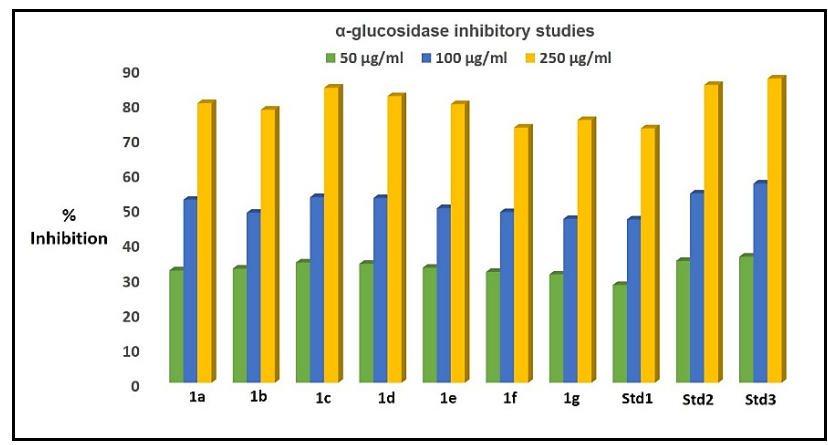

Fig.4. $\alpha$-glucosidase inhibitory efficacy of polysubstituted quinolines

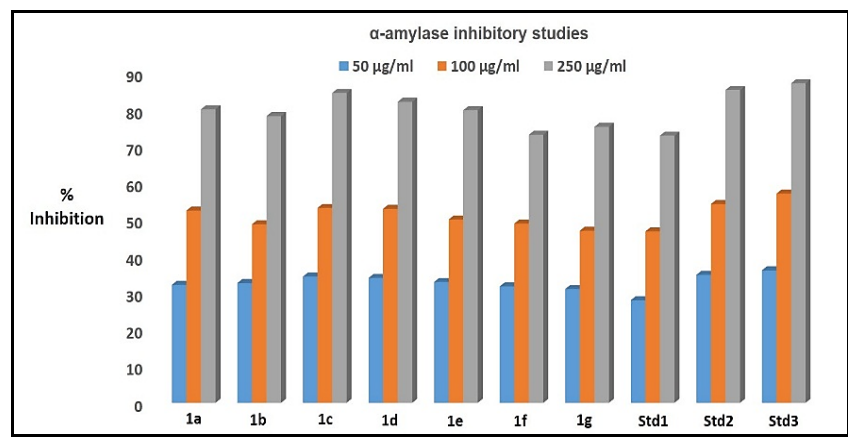

Fig.5. $\alpha$-amylase inhibitory efficacy of polysubstituted quinolines

\section{CONCLUSION}

The pharmacological role of polysubstituted quinolines towards PPAR $\gamma$ was successfully explored for their hypoglycemic efficacy. The results obtained from molecular modelling studies were consistent with in vitro hypoglycemic enzyme assays. In the present generation there is a growing need for effective therapies to achieve optimal glycemic control in the treatment of diabetes. Therefore the results obtained in the present work can be utilized for finding effective therapeutic agents in the management of diabetes. 


\section{ACKNOWLEDGMENT}

The authors sincerely thank the management of Kalasalingam Academy of Research and Education, Krishnankoil, Tamil Nadu, India for their constant encouragement and support and providing all the necessary facilities for carrying out this research work.

\section{REFERENCES}

1. M.F.Grundon, "Quinoline, quinazoline and acridone alkaloids," Nat. Pro. Rep. Vol.7, pp.131-138, 1990.

2. P.M. Hawkey, "Mechanisms of quinolone action and microbial response," J. Antimicrob. Chemoth. Vol.51, pp.29-35, 2003.

3. V.V. Kouznetsov, L.Y.V. Mendez and C.M.M. Gomez, "Recent Progress in the Synthesis of Quinolines" Curr. Org. Chem. Vol.9, pp.141-161, 2005

4. V. Kumar, A. Mahajan and K. Chibale, "Synthesis and evaluation of a novel series of quinoline derivatives with immunosuppressive activity," Bioorg. Med. Chem. Vol.17, pp.5433-5441, 2009.

5. A.K. Agrawal and S.A. Jenekhe, "Synthesis and processing of heterocyclic polymers as electronic, optoelectronic and nonlinear optical materials. New conjugated polyquinolines with electron-donar or acceptor side groups," Chem Mater. Vol. 5, pp.633-640, 1993.

6. M.I. Anderson and A.P. MacGowan, "Development of the quinolones," J. Antimicrob. Chemoth.Vol.51, pp.1-11, 2003.

7. H.I. Abd-Alla, M. Shaaban, K.A. Shaaban, N.S. Abu-Gabal, N.M. Shalaby and H. Laatsch, "New bioactive compounds from Aloe hijazensis," Nat. Pro. Res. Vol.23, pp.1035-1049, 2009.

8. J. Minville, J. Poulin, C, Dufresne, C.F. Sturino, "A general synthesis of quinolinones and benzothiazine 1,1-dioxides via ring closing metathesis," Tetrahedron Lett. Vol.49, pp.3677-3681, 2008

9. X. Guo, Y.L. Li, Y.F. Liu, H.Y. Gou and Y.C. Wang, "Synthesis and in vitro antibacterial activities of 7-(3-aminopyrrolo[3,4-c]pyrazol $-5-(2 \mathrm{H}, 4 \mathrm{H}, 6 \mathrm{H})-\mathrm{yl})$ quinolone derivatives," Chin. Chem. Lett. Vol.21, pp.1141-1144, 2010.

10. M.F. Grundon, "Quinoline, quinazoline and acridone alkaloids," Nat. Pro. Rep. Vol.7, pp.131-138, 1990.

11. J.P.Michael, "Quinoline, quinazoline and acridone alkaloids," Nat. Prod. Rep. Vol.25, pp.166-187, 2007.

12. R. Subashini, G. Angajala, K. Aggile and F. Nawaz khan, "Microwave-assisted solid acid-catalyzed synthesis of quinolinyl quinolinones and evaluation of their antibacterial, antioxidant activities," Res. Chem. Intermed.Vol.41, pp.4899-4912, 2014.

13. D. Edmont, R. Rocher, C. Plisson and J. Chenault, "Synthesis and evaluation of quinoline carboxyguanidines as antidiabetic agents," Bioorg. Med. Chem. Lett. Vol.10, pp.1831-1834, 2010.

14. G. Angajala and R. Subashini, "Nickel nanoparticles: a highly efficient and retrievable catalyst for the solventless Friedlander annulation of quinolines and their in silico molecular docking studies as histone deacetylase inhibitors," RSC Adv. Vol.5, pp.45599-45610, 2015.

15. C.P. Malik and M.B. Singh, "Plant Enzymology and Histoenzymology," Kalyani Publishers, New Delhi, Ludiana. Vol.39 pp.65-89, 1980.

16. S. Krishnaveni, B. Theymoli, S. Sadasivam, "Sugar Distribution in Sweet Stalk Sorghum," Food Chem. Vol.15, pp.229-232, 1984.

\section{AUTHORS PROFILE}

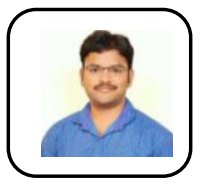

Gangadhara Angajala is working as an Assistant professor in Department of Chemistry at Kalasalingam Academy of Research and Education. He completed his under-graduation in B.Sc with triple major at Government Degree College for Men, Anantapur, Andhra Pradesh and his graduation with specialization in Pharmaceutical Chemistry at Vellore Institute of Technology, Tamil nadu. He obtained his Ph.D with specialization in Organic and Medicinal Chemistry from VIT University. His research area includes synthesis of new quinoline scaffolds with hypoglycemic efficacy by using nanocatalysis.

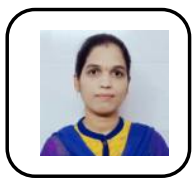

Valmiki Aruna has completed her under-graduation in B.Sc with triple major at Government Degree College for Men, Anantapur, Andhra Pradesh and currently persuing her M.Sc Chemistry at Kalasalingam Academy of Research and Education, Krishnankoil, Tamil Nadu, India.

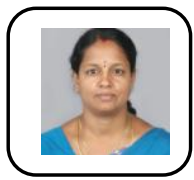

Radhakrishnan Subashini has completed her Ph.D a VIT University, Vellore in 2011. She has done M.Phil at KMCPGS, Pondicherry University, Pondicherry and M.Sc at Annamalai University, Chidambaram. She is currently working as an Assistant Professor at Arignar Tamilnadu, India Anna Government Arts College for Women, Walajapet,

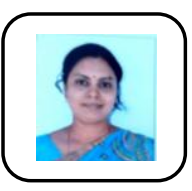

D.Geetha has completed M. Sc in Chemistry discipline from Bharathidasan University, M. Phil., from Annamalai University. She completed $\mathrm{Ph}$. D from Jaypee University in 2016. She is currently working as an Assistant professor at Kalasalingam Academy of Research and Education from 2017 onwards. Her field of interest is bio surfactant. She has published 7 papers in reputed international journals

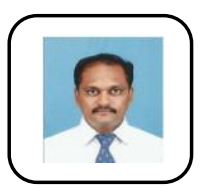

Rajajeyagantha Ramanathan completed his B.Sc. Applied Sciences from Coimbatore Institute of Technology, Coimbatore and M.Sc., Applied Chemistry from National Institute of Technology, Tiruchirappalli. He was awarded "Best Outgoing Student" with a gold medal in M.Sc. He completed his Ph.D (Surface Science) under TWAS-CNPq fellowship from Federal University of Rio Grande do Sul, RS, Brazil. 